\title{
NOTE ON THE PROTHALLUS OF LEPIDODENDRON VELTHEIM-
}

IANUM.-As the prothalli of Palaeozoic Lycopodineae are not as a rule well preserved, we know exceedingly little about the gametophyte generation of the members of this group. In the case, however, of the megaspores of Lepidodendron Veltheimianum, which occur in abundance in the Pettycur Limestone, the prothallus is never shed from the spore and occasionally its tissue is more or less perfectly preserved. In $1908^{1} \mathrm{I}$ drew attention to a specimen of this megaspore which was almost completely preserved, and in the same year Dr. Scott figured another example. ${ }^{2}$ The prothallus in my specimen showed a certain amount of differentiation into a cap of small-celled parenchyma at the apex of a larger-celled tissue. This cap was situated below the three ear-like projections of the spore coat which characterize this megaspore. As the spore coat did not show any trace of rupture (although the lines of rupture were indicated) I concluded that the specimen was immature. There were no traces of archegonia present in this example.

The megaspore figured by Dr. Scott also shows traces of this differentiation, the smaller-celled parenchyma occurring where the spore wall is ruptured; but part of the prothallus seems to have been extruded from the spore.

Recently I have obtained a specimen which, though less perfectiy preserved than either of the above, throws considerable light on the development of the archegonia. The spore coat in this example also is ruptured (the splitting probably occurring between two adjacent ear-like projections), and below this gap there is a very distinct archegonium. The only cells of the prothallus which are preserved are round the archegonium, and they are similar in size to the cells of the cap in the examples mentioned above. In the accompanying figures, for which I am indebted to Mrs. Scott, this archegonium is exceedingly well shown. Fig. I $a$ represents the whole spore with the external surface coated by knobbed hairs and the prothallus inside the spore coat. On the surface of this prothallus (which is shown more highly magnified in Fig. I $b$ ) a distinct papilla is seen. This papilla consists of the neck cells of the archegonium $\left(n . c_{.}\right)$and immediately below the neck there is a dark mass $(A)$ which probably represents the central cell. Separating the lower neck cells on the one side from those on the other is a narrow dark mass which in life would be the neck canal cell (n.c.c.).

As far then as we can judge from this specimen, the development of the archegonium in Lepidodendron Veltheimianum was essentially similar to that in Selaginella. The archegonium mother-cell appears to have been one of the superficial prothallial cells which has divided into an upper and a lower cell, as in Selaginella. By the division of the upper cell into four and the subsequent division of each of these into three, the twelve neck cells have been produced. The whole neck consists of three tiers of four cells and there is no indication that it was ever bent over. On the right-hand side of Fig. I $a$ there appear to be four neck cells in one row, but this is due no doubt to the wall between the two adjacent cells being oblique. The lower cell then appears to have divided into two, the upper forcing its way between the lower neck cells and

1 Trans. Bot. Soc., Edinburgh, vol. xxiii, 1908.

${ }^{2}$ Scott, Studies in Fossil Botany, 2nd ed., Part I, p. I88, Fig. 77, London, 1908. 
forming the neck canal cell (n.c.c.) of the archegonium, while the lower forms the central cell. The whole archegonium seems to have been almost ripe, but it had not yet opened.

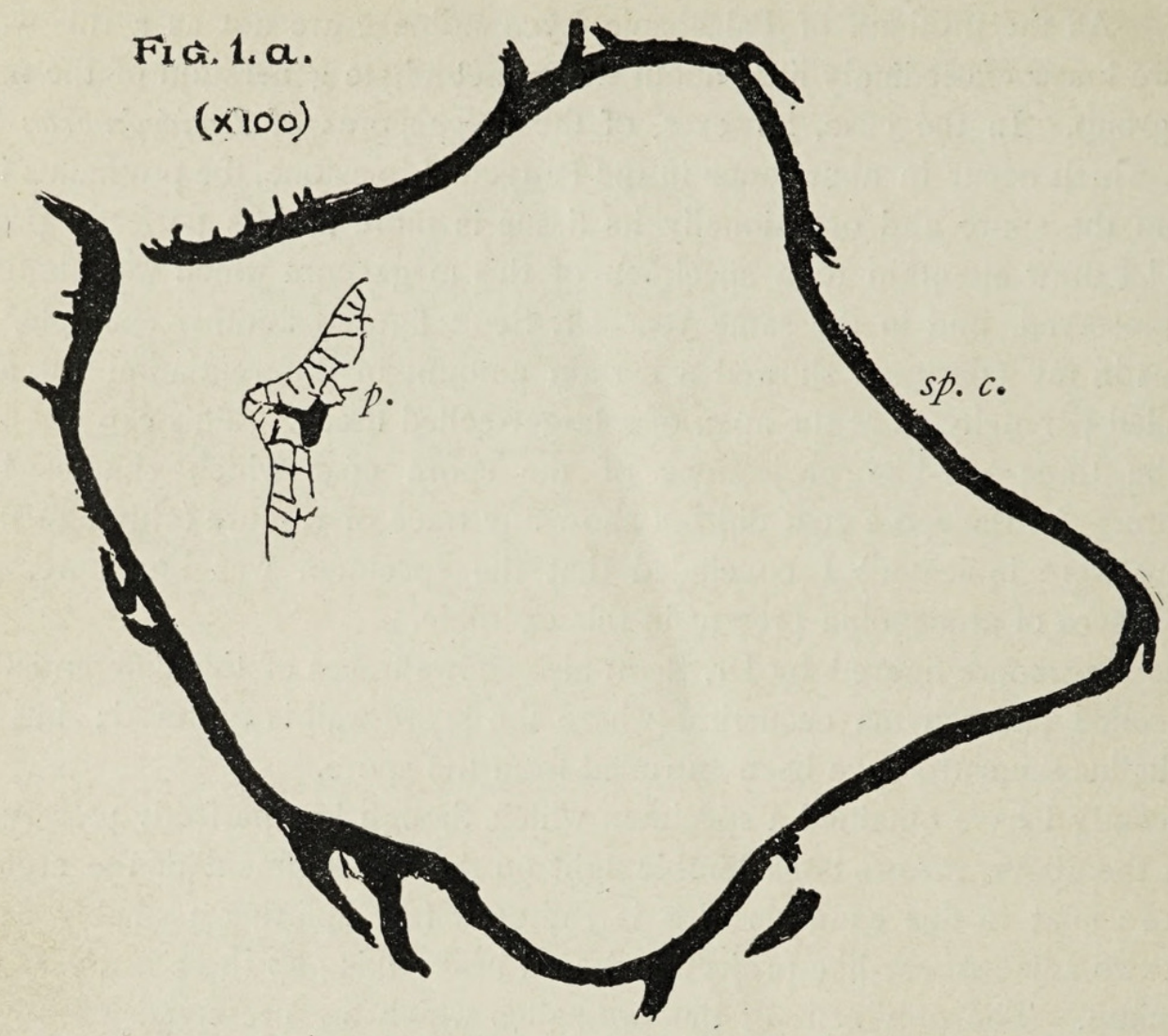

FíG.1.b,

$(\times 275)$

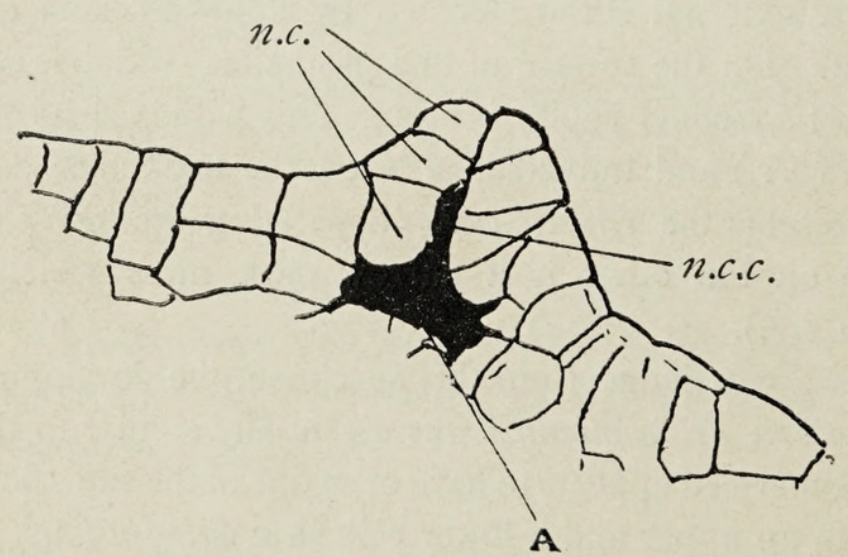
FIG. I $a$. Megaspore of L. Veltheimianum with prothallus. sp.c. = spore coat; $p .=$ prothallus.

FIG. I $b$. Prothallus of Fig. $\mathrm{I} a . A=$ central cell; n.c. $=$ neck cells; n.c.c. $=$ neck canal cell. $\times 275$. From drawings by Mrs. D. H. Scott.

The discovery of the archegonium in Lepidodendron Veltheimianum still further accentuates the similarity between the gametophyte generation of this plant (and probably of other species) and that of the living Selaginella.

W. T. GORDON. 


\section{$2 \mathrm{BHL}$ Biodiversity Heritage Library}

Gordon, W. T. 1910. "Note on the prothallus of Lepidodendron veltheimianum." Annals of botany 24, 821-822. https://doi.org/10.1093/oxfordjournals.aob.a089307.

View This Item Online: https://www.biodiversitylibrary.org/item/262605 DOI: https://doi.org/10.1093/oxfordjournals.aob.a089307

Permalink: https://www.biodiversitylibrary.org/partpdf/319815

\section{Holding Institution}

New York Botanical Garden, LuEsther T. Mertz Library

\section{Sponsored by}

BHL-SIL-FEDLINK

\section{Copyright \& Reuse}

Copyright Status: Public domain. The BHL considers that this work is no longer under copyright protection.

This document was created from content at the Biodiversity Heritage Library, the world's largest open access digital library for biodiversity literature and archives. Visit BHL at https://www.biodiversitylibrary.org. 